\title{
Arsenic removal from industrial wastewater
}

\author{
Jacek Dziubek ${ }^{1, *}$ \\ ${ }^{1}$ Gelsenwasser Polska GmbH, Dresden, Germany
}

\begin{abstract}
The article presents current research on the removal of arsenic in one of copper smelter in Legnica-Głogów Copper District. Arsenic removal technology applied in the results of previous author's researches has been described. Also, the content of arsenic in wastewater discharged into the receiver in 2012-2016 was examined. Additionally, the concentration of heavy metals in these wastewater was checked.
\end{abstract}

\section{Introduction}

The problem of excessive arsenic content in the air in the last three years in the cities belonging to Legnica-Głogów Copper District has been often the subject of intense debate in the local press or at meetings of municipal councils of each village of the region[1,2]. The problem is not trivial, because the research station of the Regional Environmental Protection Inspectorate located in Głogów has shown exceeded arsenic concentration in almost every month over the past few years, and they reach $250 \%$ of the permissible norm. Information about the risk of exceedances of permitted levels of substances in the air for 2017 shows the towns Głogów and Legnica as at risk of exceeding the annual average target level of arsenic[3]. The public opinion indicates KGHM Polska Miedź SA, a large producer of non-ferrous metals, as a potential perpetrator of exceedances. The problem of air pollution is therefore subject not only lively discussion, but also analysis and research. However, the issue of arsenic in wastewater from KGHM and the way of its treatment should be also analysed. This work is a continuation of the author's research in the years 2005-2011 and is an attempt at such analysis.

\section{Ecotoxicology of arsenic}

Arsenic belongs to the group of trace elements. This means that it is essential in the organism in some range in which. When exceeded it becomes to be toxic. The best-known and best described cases of mass poisoning by arsenic come from Asia (Bangladesh, India, Taiwan). In Bangladesh, 27\% ofshallow wells contained

\footnotetext{
*Corresponding author: jacek.dziubek@gelsenwasser.pl
} 
oversized, more than $50 \mathrm{mg} / 1$, amount of arsenic (current WHO recommendation is $10 \mathrm{mg} / \mathrm{1}$ ). Approximately 30-35 million people in this country and 6 million people in West Bengal (India) were exposed to high concentrations of arsenic in water (above $50 \mathrm{mg} / \mathrm{l}$ ), while even57 million people were exposed to concentrations between 10 and $50 \mathrm{mg} / 1$. The most common symptoms are eczema, rashes and tumours leading to skin cancer [4].Other studies indicate that the standardized mortality rate (which is the ratio of the observed death rate to the expected quantity, expressed as a percentage) for cancer of the respiratory system for persons exposed to arsenic with the contact time of more than 25 years is $833.3 \%$ [5].

Among many examples of the harmful effects of this element to the environment, national studies are worth quoting [6]. The research was conducted in the closed arsenic mine in Złoty Stok and in the immediate vicinity (the concentration of arsenic were dozens of times higher than accepted as normal for soils occurring there). A number of anomalies were showed. The most common were discoloration of plants, stunting and deformation of a whole or its parts.

A small number of indigenous species of trees and shrubs, low amount of specimen, and also the fact that the area of the mine was not inhabited by plants typical for this area after a few decades of closing the plant, is also characteristic for this area.At least 21 species of vascular plants avoid studied subsoils. Teratology changes were observed at $36.6 \%$ of vascular plants in this area.

\section{Arsenic in the technological line of KGHM Polska Miedź}

The deposits of copper sulphide LGOM contain a considerable amount of accompanying elements.Some of them are recovered in the technological processes used in KGHM Polska Miedź. Others, including arsenic, are a serious source of environmental and technological problems. Its content is complicated by, among others, processes of smelting, refining and disposal of $\mathrm{SO}_{2}$ to sulphuric acid. Therefore, arsenic belongs to the group of associated metals, where content in metallurgical processes must be regulated. While being removed from the technology it goes to the flue dust, sewage, solid waste and is secreted in the form of a sponge $\mathrm{Cu}$-As. Figure 1 illustrates a block diagram of copper production and the place of arsenic output.

Arsenic in metallurgical phases of concentrate processing accumulates in:

- by-products of galvanizing processes (dusts and sludges)

- primary production of galvanizing phase (copper matte, blister copper and finally copper anode)

- electrolyte.

Trace amounts of arsenic are present in the shaft slag, electric furnace slag and the anode sludge. Arsenic goes to the sewage system mainly from two directions: Sulfuric Acid Plants, where gases from the furnace processes are recycled and electrolyte treatment plant. 


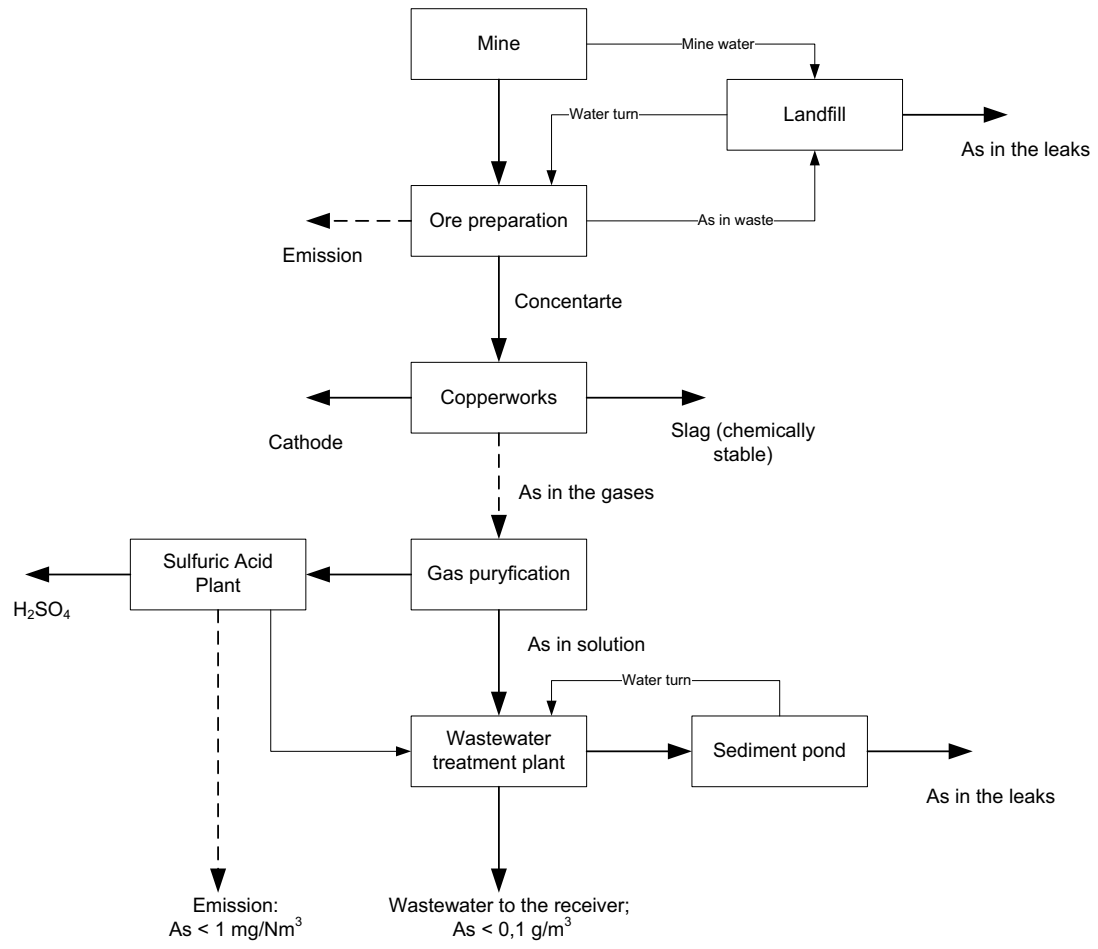

Fig. 1. Main cycles of arsenic in copper production process [based on 7].

\section{Methodsof arsenic disposal tested in the sewage treatment plants of KGHM Polska Miedź}

Due to differences in the metallurgical technology, forms and concentration of the occurring arsenic, in the configuration of the sewage system, as well as wastewater treatment technology, the removal of arsenic is carried out differently by each of the three wastewater treatment plants. Since the arsenic content in the sewage is high at all three ironworks, the concentration of arsenic is reduced in each of the wastewater treatment plant in several processes.

In order to bring all wastewater treatment plant to such state. a number of methods for removing arsenic were tested.

Due to shortage of wastewater treatment plant where such high concentrations of arsenic could be removed, methods of sewage treatment were searched for in hydrometallurgy, chemistry sulfuric acid and water purification. Relatively low cost and easy insertion into existing wastewater treatment plants wererequired.

Several methods of arsenic removal were tested:

- preparations sulphide precipitation,

- $\mathrm{Ca}(\mathrm{OH})_{2}$ precipitation,

- iron salts precipitation,

- Mineral Like Precipitation (MLP),

- electro impulse method of wastewater treatment,

- use of waste materials with a high content of iron (II),

- salts of barium precipitation. 
During application of some methods (MLP, $\mathrm{Ca}(\mathrm{OH})_{2}$ precipitation and the precipitation of the iron salts) oxidation of As (III) to As (V) was tested.

The results of some experiments have been already shown[8,9,10,11]. Generally, the usefulness of these methods for removing high concentrations of arsenic in laboratory and in real scale for all of the three treatment KGHM Polska Miedź SA was demonstrated.

\subsection{Methodology}

\subsubsection{Flowsheet}

Figure 2 shows a flowsheet for the removal of arsenic in the wastewater treatment plant of Copperworks Głogów II (HMG II).

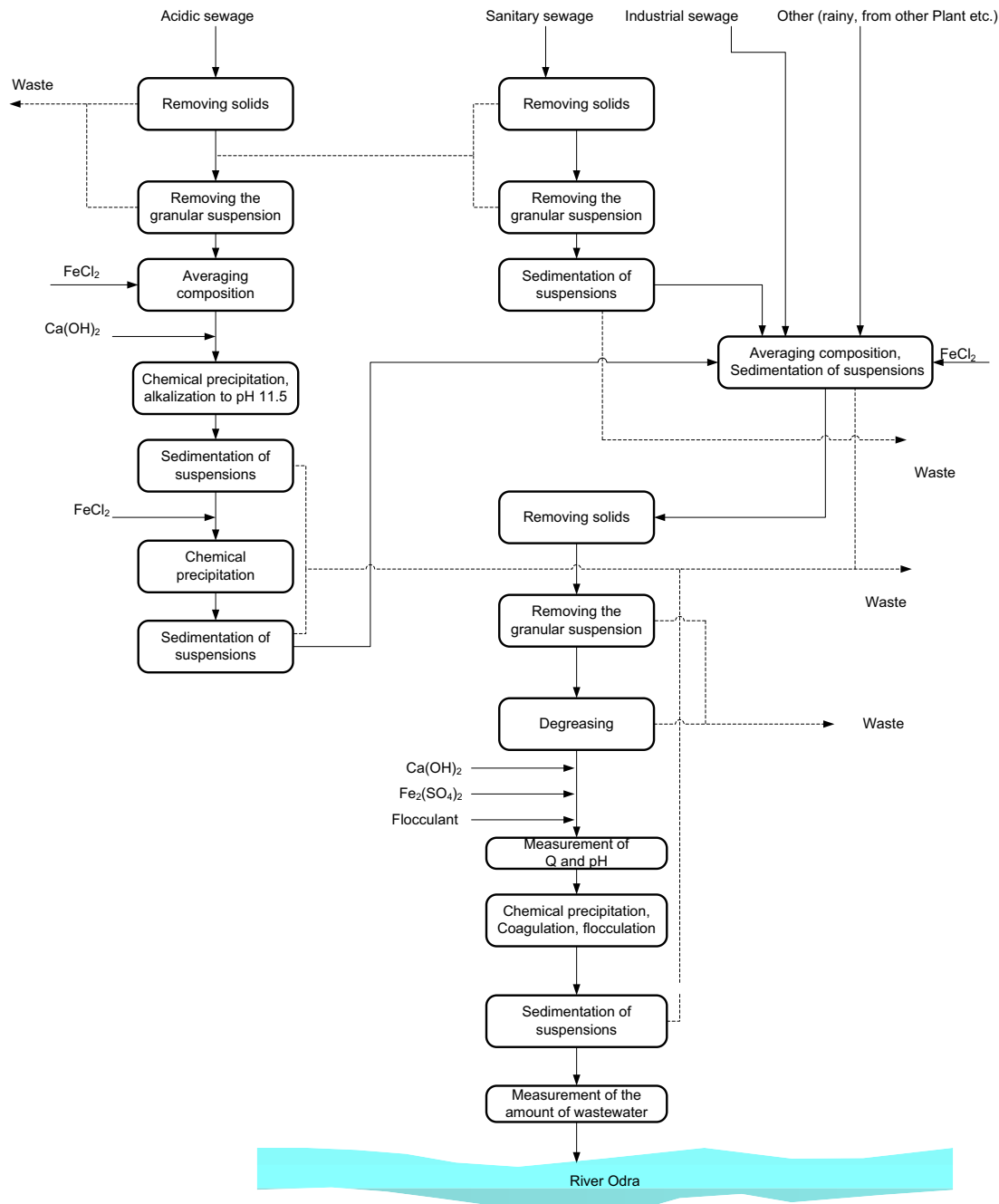

Fig. 2. Schematic diagram of sewage treatment plant HMG II. 


\subsubsection{Materials, reagents}

Calcium hydroxide.To test the precipitation of arsenic by calcium and wastewater alkalization, the $7 \%$ milk of lime (a suspension of $\mathrm{Ca}(\mathrm{OH})_{2}$ in water) was used. Milk of lime was prepared on site from hydrated lime. Supplier of hydrated lime was Lhoist Poland.

Iron salts.To test the precipitation of arsenic by iron salts, iron sulphate (PIX 113) and ferric chloride (PIX 109) (produced by Kemipol Ltd) was used.

- PIX 113 is an aqueous solution of ferrous sulphate - chemical formula $\mathrm{Fe}_{2}\left(\mathrm{SO}_{4}\right)_{3}$. The total iron content is $11.8 \% \pm 0.4 \%$ and the iron (II) $0.4 \% \pm 0.3 \%$. The density of the solution varies in the range of $1.50-1.57 \mathrm{~g} / \mathrm{cm}^{3}$. The $\mathrm{pH}$ is less than 1 .

- PIX 109 is an aqueous solution of ferric chloride, chemical formula $\mathrm{FeCl} 3$. The total iron content is $10.5 \% \pm 0.5 \%$ and the iron (II) $0.5 \%$ max. The density of the solution ranges from $1.27-1.37 \mathrm{~g} / \mathrm{cm}^{3}$. The $\mathrm{pH}$ is about 1 .

The liquid waste with a high content of Fe (II).In studies for arsenic removal by means of liquid waste with a high content of Fe (II) used technological baths from galvanizing processes from nearby galvanizing steel were used. They can be characterized by a low $\mathrm{pH}$ value $=0.7, \mathrm{Fe}$ (III) content of $1100 \mathrm{~g}$ and $150000 \mathrm{~g}$ Fe (II) per $1 \mathrm{~m}^{3}$. They are also contaminated with heavy metals (nickel, lead, copper).

\subsubsection{The composition of waste water used in tests}

The composition of raw sewage has been shown in Table 1. Other wastewater groups are not characterized by such high concentrations of arsenic (sporadically exceeding $1 \mathrm{~g} / \mathrm{m}^{3}, \max 4 \mathrm{~g} / \mathrm{m}^{3}$ ) or other pollutants, therefore their compositions was neglected. Acidic wastewater is responsible for $95 \%$ of the arsenic load flowing into the wastewater treatment plant.

Table 1. Composition of acid sewage from HMG II (2016)

[Own study based on the database from Energetyka Ltd.].

\begin{tabular}{|c|c|c|c|}
\hline & Unit & Average & Maximum \\
\hline $\mathrm{pH}$ & - & $<2.0$ & $<2.0$ \\
\hline $\mathrm{Cl}$ & {$\left[\mathrm{g} \mathrm{Cl}^{3} \mathrm{~m}^{3}\right]$} & 4876 & 8453 \\
\hline $\mathrm{SO}_{4}$ & {$\left[\mathrm{~g} \mathrm{SO}_{4} / \mathrm{m}^{3}\right]$} & 10086 & 16299 \\
\hline $\mathrm{Susp}$. & {$\left[\mathrm{g}^{3}\right]$} & 66 & 240 \\
\hline $\mathrm{COD}$ & {$\left[\mathrm{g} \mathrm{O}_{2} / \mathrm{m}^{3}\right]$} & 153 & 346 \\
\hline $\mathrm{Cu}$ & {$\left[\mathrm{g} \mathrm{Cu}^{3}\right]$} & 16 & 62 \\
\hline $\mathrm{Fe}$ & {$\left[\mathrm{g} \mathrm{Fe}^{3} \mathrm{~m}^{3}\right]$} & 19 & 22 \\
\hline $\mathrm{Pb}$ & {$\left[\mathrm{g} \mathrm{Pb} / \mathrm{m}^{3}\right]$} & 9.9 & 28 \\
\hline $\mathrm{Zn}$ & {$\left[\mathrm{g} \mathrm{Zn} / \mathrm{m}^{3}\right]$} & 4.5 & 19 \\
\hline $\mathrm{Ni}$ & {$\left[\mathrm{g} \mathrm{Ni} / \mathrm{m}^{3}\right]$} & 3.1 & 532 \\
\hline $\mathrm{As}$ & {$\left[\mathrm{g} \mathrm{As} / \mathrm{m}^{3}\right]$} & 310 & \\
\hline \multicolumn{2}{|r|}{} \\
\hline
\end{tabular}




\subsubsection{Analytical methods}

Table 2 summarizes the analytical methods used, together with standards according to which the analysis was performed.

Table 2. Analytic methods.

\begin{tabular}{|c|c|c|}
\hline Type of examination & Research method & Standard \\
\hline COD & $\begin{array}{l}\text { Spectrophotometric } \\
\text { method }\end{array}$ & PN-ISO 15705:2005 \\
\hline Chloride & Titrimetric method & PN-ISO 9297:1994 \\
\hline $\mathrm{pH}$ & Electrometric method & PN-90/C-04540/01 \\
\hline Sulfate & $\begin{array}{c}\text { Ion chromatography (IC) } \\
\text { method }\end{array}$ & PN-EN ISO 10304 \\
\hline Total Arsenic & \multirow{6}{*}{$\begin{array}{l}\text { Inductive atomic emission } \\
\text { spectrometry (ICP-OES) } \\
\text { after mineralization }\end{array}$} & \multirow{6}{*}{ PN-EN 11885:2001 } \\
\hline Zinc & & \\
\hline Copper & & \\
\hline Nickel & & \\
\hline Lead & & \\
\hline Iron & & \\
\hline
\end{tabular}

\subsubsection{A method of operation.}

Removal of pollutants in sewage treatment plants HMG II was carried out according to the scheme on Fig. 2, using the following doses of chemicals and process parameters:

- Sanitary sewage - the elimination of solids and suspensions in physical processes.

- Acidic sewage - dosage to reservoirs of waste $\mathrm{FeCl}_{2}$ at a dose of $1000 \mathrm{~g} / \mathrm{m}^{3}$. Alkalinisation carried out in reactors (until $\mathrm{pH}>11.5$ ) and the neutralization products of sedimentation in settling tanks Dora. Then precipitation / coagulation by waste liquid with high concentration of $\mathrm{FeCl}_{2}-$ a dose of $500 \mathrm{~g} / \mathrm{m}^{3}$ and sedimentation of reaction products.

- Averaging of composition in reservoirs where all wastewater goes: sanitary and acidic - after preliminary treatment and industrial and rainy-cooling water directly from the drains. In advance liquid waste with high concentration of $\mathrm{FeCl}_{2}$ (dose of $\left.150 \mathrm{~g} / \mathrm{m}^{3}\right)$ is dosed.

- In the second stage treatment, after calibration with lime milk to $\mathrm{pH}$ 8.5-9.0, process of coagulation by assisted iron (III) sulphate, assisted by an anionic polyelectrolyte was conducted (coagulant dose - $40 \mathrm{~g} / \mathrm{m}^{3}$, flocculant dose $\left.0.25-0.4 \mathrm{~g} / \mathrm{m}^{3}\right)$. 


\subsection{Results}

In the period precedingthe initiation of effective arsenic removal trials, arsenic content exceeded the permissible content of arsenic in sewage discharged into the Odra river. The wastewater treatment technology used in this period did not guarantee the attainable concentration of arsenic in the effluent from the treatment plant. The permissible concentration of arsenic, i.e. $0.1 \mathrm{~g} / \mathrm{m}^{3}$, was practically continuous. In some samples the excess was $3100 \%$ (!).

Laboratory research and technical trials led to the development of a technology that effectively eliminates arsenic from sewage. These technologies have been, therefore, implemented. As part of this work effectiveness of arsenic (and heavy metals) removal after the implementation period has been verified. The data is summarised in tables 3 and 4 .

Table 3. Arsenic concentration in effluent from sewage treatment plant HMG II

[Own study based on the database from Energetyka Ltd.].

\begin{tabular}{|c|c|c|}
\hline \multirow{2}{*}{ Year } & \multicolumn{2}{|c|}{ Arsenic concentration $\left[\mathbf{g} / \mathbf{m}^{\mathbf{3}}\right]$} \\
\cline { 2 - 3 } & Average & Maximum \\
\hline 2012 & 0.025 & 0.098 \\
\hline 2013 & 0.011 & 0.077 \\
\hline 2014 & 0.007 & 0.059 \\
\hline 2015 & 0.006 & 0.040 \\
\hline 2016 & 0.035 & 0.090 \\
\hline
\end{tabular}

Table 4. Heavy metal concentration in effluent from sewage treatment plant HMG II [Own study based on the database from Energetyka Ltd.].

\begin{tabular}{|c|c|c|c|}
\hline Heavy Metal & Unit & Average & Maximum \\
\hline $\mathrm{pH}$ & - & 8.6 & 8.9 \\
\hline $\mathrm{Cl}$ & {$\left[\mathrm{g} \mathrm{Cl}^{3}\right]$} & 940 & 1388 \\
\hline $\mathrm{SO}_{4}$ & {$\left[\mathrm{~g} \mathrm{SO}_{4} / \mathrm{m}^{3}\right]$} & 740 & 1165 \\
\hline $\mathrm{COD}$ & {$\left[\mathrm{g} \mathrm{O}_{2} / \mathrm{m}^{3}\right]$} & 23.7 & 38.2 \\
\hline $\mathrm{Cu}$ & {$\left[\mathrm{g} \mathrm{Cu}^{3}\right]$} & 0.048 & 0.075 \\
\hline $\mathrm{Fe}$ & {$\left[\mathrm{g} \mathrm{Fe} / \mathrm{m}^{3}\right]$} & 0.649 & 1.130 \\
\hline $\mathrm{Pb}$ & {$\left[\mathrm{g} \mathrm{Pb} / \mathrm{m}^{3}\right]$} & 0.118 & 0.190 \\
\hline $\mathrm{Zn}$ & {$\left[\mathrm{g} \mathrm{Zn} / \mathrm{m}^{3}\right]$} & 0.076 & 0.138 \\
\hline $\mathrm{Ni}$ & {$\left[\mathrm{g} \mathrm{Ni} / \mathrm{m}^{3}\right]$} & 0.054 & 0.119 \\
\hline $\mathrm{Ag}$ & {$\left[\mathrm{g} \mathrm{Ag} / \mathrm{m}^{3}\right]$} & 0.005 & 0.058 \\
\hline $\mathrm{Cr}$ & {$\left[\mathrm{g} \mathrm{Cr} / \mathrm{m}^{3}\right]$} & 0.005 & 0.05 \\
\hline $\mathrm{Cd}$ & {$\left[\mathrm{g} \mathrm{Cd} / \mathrm{m}^{3}\right]$} & Below the determination threshold \\
\hline $\mathrm{Hg}$ & {$\left[\mathrm{g} \mathrm{Hg} / \mathrm{m}^{3}\right]$} & \multicolumn{2}{|c}{} \\
\hline
\end{tabular}

\section{Summary}

Several years of work on the implementation of effective method of arsenic removal in wastewater treatment plant HMG II were successfully ended. Initially, the concentration of this element exceeded the limits in wastewater discharged into a receiver from several dozen to several hundred times. several methods on 
a laboratory and technical scale were tested. Some of them were tested in real conditions of operation of the plant. It has been shown that it is possible to effectively remove arsenic present in high concentrations in industrial wastewater to the level required by the law in daily work conditions.

After the initial tests, it was checked whether the proposed methods, despite changing the conditions of the infestations, still fulfilled their role. The results were positive. Within 5 years the water permit was not exceeded once. The finally proposed technologies proved to be very effective. Maximum concentrations of arsenic in wastewater discharged to the receiver do not exceed $0.1 \mathrm{~g} / \mathrm{m}^{3}$, and average values are $0.006-0.035 \mathrm{~g} \mathrm{As} / \mathrm{m}^{3}$.

It is worth pointing out that both arsenic and heavy metals in 2012-2016 in wastewater discharged to the receiver never exceeded the limit values and their mean concentrations are significantly lower than the limit values. This demonstrates the correct choice of arsenic removal technology.

\section{References}

1. http://regionfan.pl/glogow-arsen-wisi-w-powietrzu/, access: 29.03.2017

2. http://www.wroclaw.pl/10-faktow-o-czystosci-powietrza-na-dolnym-slasku, access: 19.03.2017

3. Informacja o przekroczeniach i ryzyku przekroczeń poziomów dopuszczalnych $i$ docelowych substancji $w$ powietrzu na terenie województwa dolnoślaskiego $w$ $2017 r$.http://www.wroclaw.pios.gov.pl/pliki/komunikaty/1_Inf_ryzyko_2017_0 2_21.pdf: access: 20.03.2017

4. Arsenic. Medical and Biologic Effects of Environmental Pollutants. National Academy of Sciences, Washington (1977)

5. W. Seńczuk, Toksykologia. Wydawnictwo Lekarskie PZWL, Warszawa (2004)

6. W. Giża, Zmiany teratologiczne u roślin z podloży arsenowych w Złotym Stoku. Acta Universitias Wratislaviensis No 2037, Prace Botaniczne LXXV, Wydawnictwo Uniwersytetu Wrocławskiego, Wrocław (1997)

7. KGHM, Monografia KGHM Polska Miedź S.A. Lubin (2007)

8. J. Dziubek, D. Kwaśny, Poprawa skuteczności usuwania arsenu ze ścieków przemystu miedziowego po zastosowaniu metody elektroimpulsowej oraz przy wykorzystaniu żelaza odpadowego z procesów trawienia na przykladzie oczyszczalni $Z G W H$ II. X Seminarium - Metalurgia Metali Towarzyszących. Współczesne technologie i wyzwania (2005)

9. J. Dziubek, Oczyszczanie elektroimpulsowe a elektrokoagulacja: podobieństwa $i$ różnice na przykładzie usuwania arsenu ze ścieków przemysłowych. Conference Eko-Dok III. Szklarska Poręba (2010).

10. J. Dziubek, Usuwanie arsenu ze ścieków przemysłowych. Doctoraldissertation, Politechnika Wrocławska (2012)

11. K. Majewska-Nowak, J. Dziubek, Chemiczne i elektrochemiczne stracanie arsenu występującego $w$ wysokich stężeniach $w$ ściekach $z$ przemystu metali kolorowych. Conference Eko-Dok IV. Szklarska Poręba (2012) 